\title{
Efficacy of Aloe vera Gel on Healing of Excision Wound in Sprague dawley Rats
}

\section{Efikasi Gel Lidah Buaya (Aloe vera) terhadap Kesembuhan Luka Eksisi pada Tikus Sprague dawley}

Bagus Uda Palgunadi*, Asih Rahayu, Yos Adi Prakoso

Kedokteran Hewan, Fakultas Kedokteran Hewan, Universitas Wijaya Kusuma Surabaya, Jl. Dukuh Kupang XXV No. 54 Dukuh Kupang, Kec. Dukuh Pakis, Surabaya, 60225, Jawa Timur, Indonesia. Tel.: (031) 5677577

Wound is a pathological processes in all living things. Wound includes the overlapping mechanisms. The failure in wound healing causes infection. This study aimed to analyze the efficacy of Aloe vera gel in excisionwound on the rat's back. This study used 18 male, Sprague dawley rats, and they were induced excision wound on the back. The rats were separated into 3 groups, $\mathrm{K} 1=$ control, $\mathrm{K} 2=$ treated with betadin gel, $\mathrm{K} 3=$ treated with Aloe vera gel. The therapy was given twice a day for 7 days. The wound measurement was observed in day 3 and 7 . The data were analyzed using SPSS. The result showed that Aloe vera gel potentially promote wound healing through the decrease microscopical condition of wound, reepithelialization, and deposition of collagen better than in group K1 and K2 ( $\leq \leq 0.05)$. In conclusion, Aloe vera gel promote excision wound healing in Sprague dawley rats.
OPEN ACCESS ISSN 2580-7730 (online)

Edited by: Andika Aliviameita

Reviewed by: Wimbuh Tri Widodo

*Correspondence: Bagus Uda Palgunadi bagusuda24@gmail.com

Received: 28 Mei 2021

Accepted: 27 Juni 2021

Published: 31 Juli 2021

Citation:

Prakoso YA (2021)

Efficacy of Aloe vera Gel on Healing of Excision Wound in

Sprague dawley Rats

Medicra (Journal of Medical

Laboratory Science/Technology).
Palgunadi BU, Rahayu A, and
Keywords: Aloe vera, gel, inflammation, macroscopy, wound healing

Luka merupakan proses patologis yang terjadi pada setiap makhluk hidup. Luka melibatkan proses kesembuhan yang kompleks. Kegagalan pengobatan luka berdampak pada infeksi. Penelitian ini bertujuan untuk mengobservasi efikasi gel lidah buaya (Aloe vera) terhadap kesembuhan luka eksisi pada tikus. Penelitian ini menggunakan tikus Sprague dawley sebanyak 18 ekor dibuat luka eksisi di bagian punggungnya. Tikus dibagi ke dalam 3 kelompok yaitu, $\mathrm{K} 1$ sebagai kontrol yang diterapi dengan vaselin album, K2 = diobati dengan gel betadin, dan $\mathrm{K} 3=$ diobati dengan gel lidah buaya. Terapi diberikan sehari 2 kali selama 7 hari. Pengamatan dilakukan pada hari ke 3 dan 7. Data yang diperoleh dianalisis dengan SPSS. Hasil penelitian memperlihatkan bahwa terapi dengan gel lidah buaya berpengaruh terhadap kondisi makroskopis luka eksisi, infiltrasi sel radang, epitelisasi dan kolagenasi jika dibandingkan dengan kelompok K1 dan K2 $(p \leq 0,05)$. Berdasarkan hasil penelitian disimpulkan bahwa gel lidah buaya berpotensi dalam mengobati luka eksisi pada tikus Sprague dawley. 


\section{PENDAHULUAN}

Luka merupakan kerusakan struktur anatomi jaringan yang berdampak pada terputusnya kesinambungan jaringan Milne et al. (2012). Luka banyak terjadi akibat trauma dan infeksi. Luka yang terjadi pada tubuh mahkluk hidup terutama hewan dan manusia. Luka akan mengalami perbaikan melalui suatu proses kesembuhan luka. Proses kesembuhan luka melibatkan beberapa fase yaitu hemostatis, inflamasi, proliferasi, maturasi dan remodeling. Fase hemostatis ditandai dengan peningkatan aktifitas platelet di daerah luka yang dimulai sejak awal luka terbentuk, selanjutnya diikuti fase inflamasi yang melibatkan respon seluler dan humoral Gonzalez et al. (2016).

Penanganan yang tepat pada proses inflamasi pada luka mendukung proses kesembuhan luka yang lebih baik. Penanganan inflamasi tersebut dapat dilakukan dengan menggunakan senyawa kaya antioksidan. Salah satu bahan alami yang kaya akan antioksidan adalah lidah buaya (Aloe vera) Rahmani et al. (2015). Lidah buaya merupakan tumbuhan yang banyak ditemukan di daerah tropis sepertiAfrika, Arab, India, Asia Timur, dan Asia Tenggara termasuk Indonesia. Secara tradisional lidah buaya dimanfaatkan masyarakat sebagai bahan herbal yang membantu menyembuhkan gangguan pencernaan, serta telah dikembangkan menjadi salah satu bahan kosmetik. Bagian lidah buaya yang dapat dimanfaatkan adalah bagian dalam daunnya atau yang dikenal sebagai gel Aloe vera Surjushe et al. (2008).

Gel Aloe vera mengandung senyawa aktif berupa flavonoid, terpenoid, lektin, asam lemak, kolesterol, antrakuinon, tannin, saponin, yang secara fitofarmakologi berperan sebagai antibakteri, antioksidan, antiinflamasi, dan analgesik Balan et al. (2014). Antioksidan, antiinflamasi, dan analgesic yang terkandung dalam gel Aloe vera tersebut bermanfaat bagi tubuh terutama dalam membantu proses kesembuhan luka Prakoso and Kurniasih (2018). Antibakteri yang terkandung di dalam gel Aloe vera dapat membantu mencegah dan mengatasi timbulnya infeksi pada luka.

Penelitian ini dilakukan untuk melihat efikasi gel lidah buayaterhadap luka eksisi melalui pengamatan secara makroskopis dan histopatologis.

\section{METODE}

Penelitian ini telah disetujui oleh Komisi Etik Penelitian Hewan Coba, Fakultas Kedokteran Hewan, Universitas Gadjah Mada, Yogyakarta, Indonesia.

Kegiatan penelitian ini dilaksanakan selama 6 bulan mulai dari bulan April 2020 sampai dengan Oktober 2020. Proses ekstraksi dan pemeliharaan hewan coba dilakukan di Laboratorium Farmakologi, Fakultas Kedokteran Hewan, Universitas Wijaya Kusuma Surabaya. Proses pembuatan preparat jaringan dilakukan di Departemen Patologi, Fakultas Kedokteran Hewan, Universitas Gadjah Mada.
Lidah buaya diperoleh dari Pasar Tanaman Hias, Tanggulangin, Sidoarjo. Spesies lidah buaya telah diautentikasi di balai Konservasi Tanaman Kebun Raya Purwodadi (BKT-LIPI), Jawa Timur, dan dinyatakan sebagai Aloe vera. Lidah buaya dikupas dan diambil gelnya. Gel lidah buaya direndam dengan alkohol $70 \%$ dengan perbandingan 1:2. Campuran selanjutnya dimasukkan ke dalam inkubator suhu $37^{\circ} \mathrm{C}$ untuk diuapkan selama 2 hari. Hasil yang diperoleh berupa ekstrak basah.

Pembuatan gel lidah buaya dilakukan dengan mencampur sebanyak $0,1 \%$, nipagin $0,1 \%$, dan CMC-NA $6 \%$, add vehikulum hingga $100 \%$.

Pemeliharaan hewan coba dilakukan dengan cara: Sebanyak 18 ekor tikus Sprague dawley jantan, berat 150-200 gram, umur 3 bulan diadaptasi selama 1 minggu. Pasca adaptasi tikus dicukur dan dianastesi menggunakan ketamine dan atropine. Tikus diinduksi luka eksisi berdiameter $4 \mathrm{~mm}$ di bagian punggung. Tikus dibagi ke dalam 3 kelompok, yaitu $\mathrm{K} 1$ sebagai kontrol yang diterapi dengan vaselin album, K2 = diobati dengan gel betadin, dan K3 = diobati dengan gel lidah buaya. Terapi diberikan sehari 2 kali selama 7 hari. Pengamatan dilakukan pada hari ke-3 dan ke-7.

Pengamatan makroskopis luka dilakukan dengan cara: Pengamatan proses kesembuhan luka eksisi dilakukan pada hari ke-3 dan hari ke-7. Makroskopis luka dilakukan dengan mengukur diameter luka untuk memperoleh nilai persen area luka. Pasca pengukuran diameter luka, 3 ekor tikus pada masing-masing kelompok dietanasi dan organ kulitnya diambil.

Pembuatan Preparat Histopatologis dilakukan dengan cara: sampel kulit yang telah diambil selanjutnya disimpan ke dalam formalin $10 \%$. Sampel difiksasi selama 24 jam. Setelah 24 jam, sampel didehidrasi dengan menggunakan xilol 1, xilol 2, dan xilol 3, alkohol 70\%, alkohol 80\%, dan alkohol absolut. Sampel selanjutnya diimpregnasi dan diblok dengan parafin cair suhu $42^{\circ} \mathrm{C}$ menggunakan pencetak mold. Sampel yang terblok selanjutnya dipotong menggunakan mikrotom. Ketebalan yang digunakan yaitu $5 \mu \mathrm{m}$. Sampel dicat menggunakan pengecatan hematoksilin dan eosin untuk pengamatan jaringan rutin Feldman and Wolfe (2014). Pengamatan kolagen dilakukan dengan pengecatan Mallory Wolun-Cholewa et al. (2010).

Pengamatan histopatologi dilakukan terhadap beberapa parameter yaitu jumlah infiltrasi sel radang, reepitelisasi, dan deposisi kolagen. Pengamatan dilakukan dengan perangkatlunak Image J. Hasil ditabulasikan dan selanjutnya dilakukan analisa data statistik. Berdasarkan hasil penelitian, data yang diperoleh adalah data kuantitatif. Data kuantitatif dianalisa dengan uji parametrik menggunakan SPSS versi 16. Tingkat kepercayaan yang digunakan sebesar $95 \%$.

\section{HASIL DAN PEMBAHASAN}

Penurunan persentase area luka pada hari ke 3 hingga hari ke 7 terjadi pada semua kelompok perlakuan. Kelompok kon- 
(K1) memperlihatkan penurunan persentase area luka terjadi perlahan. Pada kelompok gel betadine (K2) dan kelompok gel lidah buaya (K3) memperlihatkan penurunan persentase area luka yang tajam pada hari ke-3 dan ke-7 secara signifikan ( $\mathrm{p} \leq 0,05)$ jika dibandingkan dengan K1 (Tabel 1).

Kesembuhan luka salah satunya ditandai dengan penurunan jumlah infiltrasi sel radang pada jaringan luka. Hasil statistik terhadap jumlah sel radang pada luka kulit tikus perlakuan menunjukkan adanya perbedaan $(\mathrm{p} \leq 0,05)$. Infiltrasi sel radang kelompok K3 dan K2 berbeda jika dibandingkan dengan $\mathrm{K} 1 \quad(\mathrm{p} \leq 0,05)$. Hal tersebut menunjukkan bahwa gel lidah buayaberpengaruh terhadap penurunan infiltrasi sel radang pada luka. Infiltrasi sel radang kelompok K2 yang diterapi dengan gel betadine tidak berbeda jika dibandingkan dengan $\mathrm{K} 1$ di hari ke-3 ( $\mathrm{p} \geq 0,05)$, dan memperlihatkan perbedaan di hari ke-7 $(\mathrm{p} \leq 0,05)$ (Tabel 2).

Hasil pengukuran ketebalan epidermis dari semua kelompok perlakuan mengalami peningkatan. Ketebalan epidermis luka kulit tikus selanjutnya diuji menggunakan uji statistik 2 arah. Hasil uji statistik memperlihatkan adanya perbedaan yang nyata $(\mathrm{p} \leq 0,05)$. Ketebalan epidermis luka kulit tikus kelompok K3 berbeda nyata jika dibandingkan dengan kelompok K1 dan K2 ( $\leq \leq 0,05)$. Hal ini menunjukkan bahwa gel lidah buaya berpengaruh terhadap peningkatan ketebalan epidermis jaringan luka. Nilai rerata dan standar deviasi ketebalan epidermis luka kulit tikus perlakuan pada hari ke-3 dan ke-7 dapat dilihat pada Tabel 3.

Kesembuhan luka yang baik diikuti dengan adanya deposisi kolagen yang lebih padat seiring dengan periode kesembuhan. Deposisi kolagen merupakan indikator perbaikan matriks jaringan. Kolagen pada kelompok K2 dan K3 memperlihatkan hasil yang lebih baik jika dibandingkan dengan kelompok K1 $(\mathrm{p} \leq 0,05)$. Hal tersebut terlihat pada hari ke-3 dan ke-7 selama periode pengamatan. Namun, tidak terdapat perbedaan yang signifikan antara kelompok K2 dan $\mathrm{K} 3$ terhadap deposisi kolagen baik pada hari ke -3 dan 7 (Tabel 4). Hal ini menunjukkan bahwa, betadine dan gel Aloe vera memiliki efek yang serupa terhadap deposisi kolagen.

Pengamatan terhadap persentase area luka dapat digunakan sebagai alat bantu dalam menentukan jenis penanganan dan terapi yang tepat pada luka. Kesembuhan luka secara makroskopis pada penelitian ini nampak terbentuk dari tepi luka, seperti yang dikemukakan oleh Kumar et al. (2013) bahwa kesembuhan luka dimulai dari tepi luka. Semakin kecil persentase luka jika dibandingkan dengan kondisi luka awal menunjukkan bahwa kesembuhan luka telah berjalan lebih baik Chang et al. (2011).

Inflamasi merupakan salah satu fase penting yang terjadi pada suatu kesembuhan luka. Inflamasi terjadi setelah terbentuk clot di permukaan luka. Inflamasi secara mikrokopis ditandai dengan adanya sel radang yang menginfiltrasi jaringan.

Penurunan jumlah sel radang pada semua kelompok menandakan bahwa proses kesembuhan luka terjadi baik pada kelompok kontrol dan terapi. Kelompok K3 memperlihatkan jumlah sel radang yang lebih sedikit jika dibandingkan $\mathrm{K} 1$ dan $\mathrm{K} 2$, sehingga dapat dikatakan bahwa aplikasi topikal gel lidah buaya dapat mempercepat durasi inflamasi. Hal tersebut diduga karena efek anti-inflamasi yang dimiliki lidah buaya. Fungsi anti-inflamasi yang dimiliki lidah buaya diperankan oleh anthraquinone dengan menghambat jalur siklo-oksigenase dan prostaglandin Zhang et al. (2018). Cethacin tannin dalam lidah buaya berperan sebagai anti-phospholipase A2 (anti-PLA2), yang diketahui bahwa PLA merupakan salah satu dari grup enzim IIA yang berperan sebagai proinflamasi. Lidah buaya juga diketahui dapat menurunkan jumlah adhesi leukosit di jaringan yang mengalami luka bakar Wen et al. (2012).

Kelompok K3 yang diterapi dengan gel lidah buaya memperlihatkan perbedaan yang nyata terhadap pembentukan epidermis luka kulit tikus perlakuan, jika dibandingkan dengan kelompok kontrol dan gel betadine $(\mathrm{p} \leq 0,05)$. Secara kualitatif telah terbentuk epidermis yang sempurna pada kelompok K3 pada hari ke-7, sedangkan pada kelompok betadine pada hari yang sama masih memperlihatkan adanya clot di permukaan luka, begitu pula dengan kelompok kontrol. Penelitian ini membuktikan bahwa aplikasi topikal gel lidah buaya berpengaruh terhadap re-epitelisasi epidermis pada luka. Aplikasi gel lidah buayapada luka diduga meningkatkan aktivasi keratinosit secara maksimal, karena keratinosit merupakan faktor utama yang membantu reepitelisasi, proliferasi dan maturasi epidermis Lugo et al. (2011). Senyawa dalam lidah buaya yang diduga berperan penting pada re-epitelisasi epidermis adalah anthraquinone, dengan melalui hambatan jalur siklo-oksigenase pada produksi prostaglandin. Glikoprotein dan lektin diduga turut berperan sebagai promotor kesembuhan luka Radha and Laxmipriya (2014).

Pada proses kesembuhan, sintesis kolagen terjadi pada fase maturasi jaringan atau terjadi setelah melalui fase inflamasi dan proliferasi jaringan. Pada fase proliferasi, fibroblas mensintesis kolagen tipe III untuk meningkatkan afinitas dan densitas jaringan sementara, atau dikenal sebagai temporary extracellular matrix (tECM) Ceyssens et al. (2017). Ketika densitas jaringan dan struktur sel telah stabil selanjutnya secara berangsur kolagen tipe III terdegradasi oleh kolagenase yang juga dilepaskan oleh fibroblas dan digantikan dengan kolagen tipe I pada proses remodeling. Densitas kolagen yang tinggi selanjutnya berdampak pada peningkatan tegangan kulit DePhillipo et al. (2018).

TABEL 1. Rerata \pm Standar Deviasi (SD) Persentase Area Luka Kulit Tikus Hari Ke-3 dan Ke-7 dari Semua Kelompok Perlakuan
Kelompok

$\mathrm{K} 1$

$\mathrm{K} 2$

K3
Rerata \pm SD hari ke

3

$60,54 \pm 1,37^{\mathrm{a}, \mathrm{a}}$
$45,29 \pm 0,81^{\mathrm{b}, \mathrm{a}}$
$35,57 \pm 10,62^{\mathrm{b}, \mathrm{a}}$
7

$45,01 \pm 2,06^{\mathrm{a}, \mathrm{b}}$

$1,70 \pm 2,74^{\mathrm{b}, \mathrm{b}}$

$0,00 \pm 0,00^{\mathrm{b}, \mathrm{b}}$ $\overline{a, b, c}$ Superskrip yang berbeda pada kolom dan baris yang sama menunjukkan perbedaan yang nyata $(p \leq 0,05)$. 
TABEL 2. Rerata \pm Standar Deviasi (SD) Sel Radang pada Luka Kulit Tikus Hari Ke-3 dan Ke-7 dari Semua Kelompok Perlakuan

Kelompok

$$
\text { Rerata } \pm \text { SD hari ke-... }
$$

3

$$
7
$$

$\begin{array}{lcc}\text { K1 } & 235,67 \pm 73,32^{\mathrm{a}, \mathrm{a}} & 138,00 \pm 29,81^{\mathrm{a}, \mathrm{a}} \\ \text { K2 } & 200,67 \pm 57,36^{\mathrm{a}, \mathrm{a}} & 69,33 \pm 18,61^{\mathrm{a}, \mathrm{b}} \\ \text { K3 } & 118,00 \pm 25,35^{\mathrm{b}, \mathrm{a}} & 49,33 \pm 28,53^{\mathrm{b}, \mathrm{c}}\end{array}$

a,b,c Superskrip yang berbeda pada kolom dan baris yang sama menunjukkan perbedaan yang nyata $(p \leq 0,05)$.

TABEL 3. Rerata \pm Standar Deviasi (SD) Ketebalan Epidermis Luka Kulit Tikus Hari Ke-3 dan Ke-7 dari Semua Kelompok Perlakuan

\begin{tabular}{ccc} 
Kelompok & \multicolumn{2}{c}{ Rerata \pm SD hari ke- $\ldots$} \\
& 3 & 7 \\
K1 & $17,73 \pm 5,70 \mathrm{a}, \mathrm{a}$ & $21,43 \pm 2,86 \mathrm{a}, \mathrm{a}$ \\
K2 & $23,67 \pm 3,27 \mathrm{a}, \mathrm{a}$ & $23,61 \pm 3,10 \mathrm{a}, \mathrm{a}$ \\
K3 & $34,17 \pm 2,73 \mathrm{~b}, \mathrm{a}$ & $36,88 \pm 5,79 \mathrm{~b}, \mathrm{a}$
\end{tabular}

\begin{abstract}
$\overline{a, b, c}$ Superskrip yang berbeda pada kolom dan baris yang sama menunjukkan perbedaan yang nyata $(p \leq 0,05)$.
\end{abstract}

TABEL 4. Rerata \pm Standar Deviasi (SD) Deposisi Kolagen Luka Kulit Tikus Hari Ke-3 dan Ke-7 dari Semua Kelompok Perlakuan
Kelompok

$\mathrm{K} 1$

$\mathrm{K} 2$

$\mathrm{K} 3$
Rerata \pm SD hari ke

3

$$
\begin{aligned}
& 0,33 \pm 0,57^{\mathrm{a}, a} \\
& 1,66 \pm 0,57^{\mathrm{b}, \mathrm{b}}
\end{aligned}
$$$$
2,33 \pm 0,57^{\mathrm{b}, \mathrm{b}}
$$

${ }^{a, 0, c}$ Superskrip yang berbeda pada kolom dan baris yang sama menunjukkan perbedaan yang nyata $(p \leq 0,05)$.

\section{KESIMPULAN}

Berdasarkan hasil penelitian ini dapat disimpulkan bahwa aplikasi topikal gel lidah buaya mendukung kesembuhan luka eksisi secara amkroskopis, menurunkan keradangan, meningkatkan ketebalan epidermis dan kolagen.

\section{KONTRIBUSI PENULIS}

Penulis pertama berperan utama dalam pengumpulan data, sedangkan penulis kedua dan ketiga membantu dalam penyusunan artikel.

\section{PENDANAAN}

Sebagian penelitian ini didanai melalui Hibah Internal tahun 2020, Universitas Wijaya Kusuma Surabaya.

\section{UCAPAN TERIMA KASIH}

Peneliti mengucapkan terima kasih kepada seluruh tenaga staf Laboratorium Patologi, Fakultas Kedokteran Hewan, Universitas Gadjah Mada atas bantuannya dalam pemrosesan jaringan.

\section{REFERENSI}

Bałan, B. J., Niemcewicz, M., Kocik, J., Jung, L., Skopińska-Różewska, E., \& Skopiński, P. (2014). Oral administration of Aloe vera gel, anti-microbial and anti-inflammatory herbal remedy, stimulates cell-mediated immunity and antibody production in a mouse model. Central-European journal of immunology, 39(2), 125-130. https://doi.org/10.5114/ceji.2014.43711.

Ceyssens, F., Deprez, M., Turner, N., Kil, D., van Kuyck, K., Welkenhuysen, M., Nuttin, B., Badylak, S., \& Puers, R. (2017). Extracellular matrix proteins as temporary coating for thin-film neural implants. Journal of neural engineering, 14(1), $\quad 014001 . \quad \mathrm{https} / / /$ doi.org/10.1088/1741$2552 / 14 / 1 / 014001$.

Chang, A. C., Dearman, B., \& Greenwood, J. E. (2011). A comparison of wound area measurement techniques: visitrak versus photography. Eplastv, 11, e18.

DePhillipo, N. N., Aman, Z. S., Kennedy, M. I., Begley, J. P., Moatshe, G., \& LaPrade, R. F. (2018). Efficacy of Vitamin C Supplementation on Collagen Synthesis and Oxidative Stress After Musculoskeletal Injuries: A Systematic Review. Orthopaedic journal of sports medicine, 6(10), 2325967118804544. https://doi.org/10.1177/2325967118804544.

Feldman, A. T., \& Wolfe, D. (2014). Tissue processing and hematoxylin and eosin staining. Methods in molecular biology (Clifton, N.J.), 1180, 31-43. https://doi.org/10.1007/978-1-4939-1050-2_3.

Gonzalez, A. C., Costa, T. F., Andrade, Z. A., \& Medrado, A. R. (2016). Wound healing - A literature review. Anais brasileiros de dermatologia, 91(5), 614620. https://doi.org/10.1590/abd1806-4841.20164741.

Kumar, V., Abbas, A. K., \& Aster, J. C. 2013. Robbins BasicPathology. $9^{\text {th }}$ Ed. Elsevier. Philadelphia. Pp. 29-72.

Lugo, L. M., Lei, P., \& Andreadis, S. T. (2011). Vascularization of the dermal support enhances wound re-epithelialization by in situ delivery of epidermal keratinocytes. Tissue engineering. Part A, 17(5-6), 665-675. https://doi.org/10.1089/ten.TEA.2010.0125.

Milne, C. T., Paine, T., Sullivan, V., \& Sawyer, A. (2012). Content validation of terms and definitions in a wound glossary. The iournal of the American College of Clinical Wound Specialists, 3(4), 7176.https://doi.org/10.1016/i.jcws.2012.07.001.

Prakoso, Y. A., \& Kurniasih (2018). The Effects of Aloe vera Cream on the Expression of $\mathrm{CD}^{+}$and $\mathrm{CD} 8^{+}$Lymphocytes in Skin Wound Healing. Journal of tropical medicine, 2018, 6218303.https://doi.org/10.1155/2018/6218303.

Radha, M. H., \& Laxmipriya, N. P. (2014). Evaluation of biological properties and clinical effectiveness of Aloe vera: A systematic review. Journal of traditional and complementary medicine, 5(1), 21-26. https://doi.org/10.1016/.j.jtcme.2014.10.006.

Rahmani, A. H., Aldebasi, Y. H., Srikar, S., Khan, A. A., \& Aly, S. M. (2015). Aloe vera: Potential candidate in health management via modulation of biological activities. Pharmacognosy reviews, 9(18), 120-126. https://doi.org/10.4103/0973-7847.162118.

Surjushe, A., Vasani, R., \& Saple, D. G. (2008). Aloe vera: a short review. Indian iournal of dermatology, 53(4), 163-166. https://doi.org/10.4103/0019-5154.44785.

Wen, C. C., Chen, H. M., \& Yang, N. S. (2012). Developing Phytocompounds from Medicinal Plants as Immunomodulators. Advances in botanical research, 62, 197-272. https://doi.org/10.1016/B978-0-12-394591-4.000040.

Wołuń-Cholewa, M., Szymanowski, K., Andrusiewicz, M., Szczerba, A., \& Warchoł, J. B. (2010). Trichrome Mallory's stain may indicate differential rates of RNA synthesis in eutopic and ectopic endometrium. Folia Histochem Cytobiol, 48(1), 148-52. https://doi.org/10.2478/v10042-0080106-4

Zhang, S., Liu, Y., Zhang, X., Zhu, D., Qi, X., Cao, X., Fang, Y., Che, Y., Han, Z. C., He, Z. X., Han, Z., \& Li, Z. (2018). Prostaglandin $\mathrm{E}_{2}$ hydrogel improves cutaneous wound healing via M2 macrophages polarization. Theranostics, 8(19), 5348-5361. https://doi.org/10.7150/thno.27385.

Conflict of Interest Statement: The authors declare that the research was conducted in the absence of any commercial or financial relationships that could be construed as a potential conflict of interest.

Copyright (๑) 2021 Palgunadi, Rahayu and Prakoso. This is an open-access article distributed under the terms of the Creative Commons Attribution License (CC BY). The use, dis- tribution or reproduction in other forums is permitted, provided the original author(s) and the copyright owner(s) are credited and that the original publication in this jour- nal is cited, in accordance with accepted academic practice. No use, distribution or reproduction is permitted which does not comply with these terms. 